\title{
ANALISIS PROKSIMAT DAN TOKSISITAS AKUT EKSTRAK DAUN SIRIH MERAH YANG BERPOTENSI SEBAGAI ANTIDIABETES
}

(Proximate Analysis and Acute Toxicitiy of Piper crocatum Leaves Extract as Potential Antidiabetics)

\author{
Mega Safithri ${ }^{1 *}$, Farah Fahma², dan Paramitha Wirdani Ningsih Marlina ${ }^{1}$ \\ 1 Departemen Biokimia, Fakultas Matematika dan IPA (FMIPA), Institut Pertanian Bogor, \\ Jl. Raya Darmaga, 16680 \\ ${ }^{2}$ Departemen Teknologi Industri Pertanian, Fakultas Teknologi Pertanian (FATETA), Institut Pertanian Bogor, \\ Jl. Raya Darmaga, 16680
}

\begin{abstract}
The aim of this study was to explore the analysis proximate and toxicity of the decoctions of P. crocatum. Fresh leaves of $\mathrm{P}$. crocatum were boiled in water in order to obtain decoction and were examined for its chemical compounds by using SNI 01-2891-1992 method for proximate analysis. Toxicity of decoction extract of $\mathrm{P}$. crocatum was orally fed to rats (Sprague dawley). The results showed that $\mathrm{P}$. crocatum leaves contains $9.27 \%$ water, $14.33 \%$ ash, $3.96 \%$ fat, $22.63 \%$ proteins, and $59.08 \%$ carbohydrates. Acute toxicity test showed that all rats were still alive after 7 days treatment with P. crocatum decoction for all dose groups $(0,5$, 10 , and $20 \mathrm{~g} / \mathrm{kg} \mathrm{BB}) . L C_{50}$ value of $\mathrm{P}$. crocatum decoction was $544.82 \mathrm{ppm}$, meaning that the decoction was relatively harmless and bioactive.
\end{abstract}

Key words: Piper crocatum, proximate analysis, toxicity, antidiabetic

\begin{abstract}
ABSTRAK
Penelitian ini bertujuan menentukan kadar air, abu, protein, lemak, dan karbohidrat dari rebusan daun sirih merah (Piper crocatum) serta mempelajari toksisitasnya. Daun segar sirih merah direbus dalam air mendidih untuk mendapatkan dekokta/rebusan yang akan dianalisis kandungan senyawa kimianya menggunakan metode SNI 01-2891-1992. Uji toksisitas menggunakan tikus putih galur Sprague dawley untuk menentukan $\mathrm{LD}_{50}$ nya dan menggunakan larva udang untuk menentukan $\mathrm{LC}_{50}$ nya. Hasil analisis proksimat menunjukkan bahwa daun sirih merah mengandung $9.27 \%$ air, $14.33 \%$ abu, 3.96\% lemak, $22.63 \%$ protein, dan $59.08 \%$ karbohidrat. Hasil uji toksisitas menunjukkan bahwa selama 24 jam sampai 7 hari setelah diberikan dekokta, tidak ada tikus yang mati pada semua kelompok dosis $(0,5,10$, maupun $20 \mathrm{~g} / \mathrm{kg} \mathrm{BB}$ ). Tidak adanya kematian pada semua dosis yang diujikan dapat dikatakan bahwa dekokta sirih merah tidak toksik. Nilai $\mathrm{LC}_{50}$ untuk air rebusan sirih merah terjadi pada konsentrasi $544.82 \mathrm{ppm}$. Hal ini menunjukkan bahwa air rebusan sirih merah memiliki potensi bioaktivitas.
\end{abstract}

Kata kunci: Piper crocatum, analisis proksimat, toksisitas, antidiabetes

"Korespondensi: Departemen Biokimia FMIPA IPB, Gedung FAPET Lt. 5, Wing 5 Kampus IPB Darmaga, Bogor Tel/fax: (0251) 8423267; Email: mega_safithri@yahoo.com/safithri@ipb.ac.id 


\section{PENDAHULUAN}

Diabetes mellitus tidak hanya menjadi masalah negara maju saja tetapi juga di negara berkembang seperti Indonesia. Proyeksi statistik jumlah penderita diabetes di Indonesia menyatakanakan terjadinya peningkatan dari 5.6 juta pada tahun 2001 menjadi 8.2 juta pada tahun 2020 . Saat ini Indonesia menempati urutan ke-4 tertinggi di dunia setelah India, Cina, dan Amerika Serikat (King et al. 1998; Boyle et al. 2001). Diabetes mellitus dapat diklasifikasikan menjadi empat kelompok, yaitu diabetes mellitus tipe I, tipe II, diabetes mellitus karena kehamilan, dan diabetes mellitus tipe sekunder akibat kerusakan pankreas. Diabetes mellitus tipe 1 dapat terjadi karena interaksi kompleks genetik dengan faktor lingkungan. Diabetes mellitus tipe 1 merupakan penyakit diabetes mellitus yang tergantung pada insulin dari luar tubuh untuk menurunkan kadar glukosa darah karena sel- $B$ pankreas penderita tidak mampu memproduksi insulin dalam jumlah mencukupi akibat proses autoimun tubuh atau serangan virus. Diabetes mellitus tipe 2 merupakan penyakit diabetes yang paling banyak terjadi (90-95\% kasus). Diabetes mellitus tipe 2 sangat berhubungan de- ngan keadaan resistensi yang biasanya disebabkan oleh obesitas (Bowman \& Russel 2001). Stres oksidatif yang terjadi dapat menimbulkan radikal bebas di dalam tubuh, dan akan mengganggu kerja insulin sehingga insulin tidak maksimal dalam menurunkan kadar glukosa darah. Selain itu, keadaan hiperglikemia akan dapat memproduksi banyak radikal bebas (Ceriello 2003), dan kondisi hiperglikemia kronis pada diabetes dapat menyebabkan terjadinya autooksidasi glukosa (Dobretsov et al. 2007). Senyawa radikal bebas yang terbentuk dalam jumlah besar akan meningkatkan stres oksidatif dan semakin banyak merusak senyawa-senyawa makromolekul lainnya seperti lipida dan protein. Kerusakan makromolekul tersebut akan menyebabkan penurunan fungsi kerja organ sehingga menimbulkan penyakit lainnya, seperti kebutaan, gagal ginjal, dan aterosklerosis (Maritim et al. 2003).

Biaya pengobatan yang tinggi untuk pengobatan diabetes mellitus membuat komisi ahli diabetes melitus WHO pada tahun 1980 merekomendasikan penggunaan bahan alami, seperti tanaman, sebagai bahan yang dapat digunakan dalam pencegahan dan penyembuhan penyakit diabetes melitus. Ada 46 jenis tanaman yang telah mendapat perhatian karena aktivitas antidiabetesnya (Widowati et al. 1997) akan tetapi sirih merah belum termasuk di dalamnya. Hasil penelitian Safithri dan Fahma (2008) menunjukkan bahwa rebusan daun sirih mengandung alkaloid, flavonoid, dan tanin. Air rebusan tersebut dapat menurunkan kadar glukosa darah tikus sebesar $38 \%$ setelah diberikan selama 10 hari dengan dosis $20 \mathrm{~g} / \mathrm{kg}$ BB. Selain itu, air rebusan juga dapat menekan penurunan bobot badan tikus tersebut. Namun demikian, sampai sekarang belum ada penelitian mengenai analisis proksimat dan toksisitas akut pada hewan uji. Analisis proksimat sirih merah penting dilakukan untuk mengidentifikasi zat makanan yang belum diketahui sebelumnya, sehingga apabila air rebusan sirih merah ini akan dikembangkan menjadi minuman fungsional data hasil analisis proksimat dapat digunakan sebagai data awal. Air rebusan sirih merah perlu dilakukan uji toksisitas, karena air rebusan potensial dikembangkan menjadi minuman fungsional, sehingga diperlukan uji toksisitas akut untuk mengetahui dosis yang aman untuk dikonsumsi. Penelitian ini bertujuan mengetahui kandungan senyawa kimia dan toksisitas akut rebusan sirih merah.

\section{METODE}

\section{Bahan dan Alat}

Bahan yang digunakan untuk diteliti adalah daun sirih merah segar diperoleh dari kebun tanaman obat IPB. Daun yang digunakan adalah daun tua tanpa tangkai. Bahan kimia yang digunakan untuk analisis proksimat terdiri atas kjeltab (tablet berisi $\mathrm{K}_{2} \mathrm{SO}_{4}$ dan selenium), $\mathrm{H}_{2} \mathrm{SO}_{4}$, dan petroleum benzena. Bahan-bahan tersebut diperoleh dari laboratorium pengujian nutrisi Pusat Penelitian Biologi, LIPI. Bahan yang digunakan untuk analisis toksisitas akut adalah tikus putih galur Spraque dawley dengan jenis kelamin jantan, sehat, dan mempunyai aktivitas normal, berusia 3-4 bulan dengan berat badan 200-350 gram yang diperoleh dari BPOM RI dan larva udang serta air laut dari laboratorium Biokimia FMIPA IPB. Alat yang digunakan untuk analisis proksimat, yaitu kjeltec dan perangkat destruksi.

\section{Pembuatan Rebusan Daun Sirih Merah}

Pembuatan rebusan daun sirih merah dilakukan berdasarkan metode Safithri dan Fahma (2008). Daun sirih merah segar ditimbang sebanyak $50 \mathrm{~g}$, ditambahkan akuades sebanyak $250 \mathrm{~mL}$, lalu direbus dengan air mendidih sampai volumenya menjadi 25 $\mathrm{mL}$. Setelah itu rebusan disaring untuk mendapatkan ekstrak air daun sirih merah.

\section{Analisis Proksimat}

Analisis proksimat dilakukan berdasarkan metode SNI 01-2891-1992 yang dimodifikasi dan dilakukan 3 kali ulangan.

\section{Kadar air}

Cawan porselin dikeringkan dalam oven $105^{\circ} \mathrm{C}$ selama 3 jam, kemudian ditempatkan dalam desikator selama 1 jam. Setelah itu ditimbang dengan neraca sartorius (a). Lalu ke dalam cawan ditambahkan sebanyak 2.0-2.5 g sampel (b). Cawan yang berisi sampel ditempatkan dalam oven $105^{\circ} \mathrm{C}$ selama 
3 jam. Setelah itu ditempatkan dalam desikator selama 1 jam. Bobot cawan dan sampel ditimbang (c). Pengeringan dilakukan beberapa kali sampai bobot sampel yang diperoleh konstan. Analisis dilakukan 3 kali ulangan untuk masing-masing sampel.

$$
\begin{gathered}
\text { \%Bobot kering }(B K)=\frac{(c-a)}{b} \times 100 \% \\
\text { \%Kadar air }=100-\% B K
\end{gathered}
$$

\section{Analisis kadar abu}

Cawan porselin dikeringkan dalam oven $1050 \mathrm{C}$ selama 3 jam, kemudian ditempatkan dalam desikator selama 1 jam. Setelah itu cawan ditimbang dengan neraca sartorius (a). Lalu ke dalam cawan ditambahkan sebanyak 2.0-2.5 g sampel hasil preparasi (b). Cawan dan sampel tersebut dikeringkan dalam tanur listrik $550^{\circ} \mathrm{C}$ selama $18-24$ jam. Sampel yang telah jadi abu kemudian ditempatkan dalam desikator selama 1 jam. Bobot cawan dan abu ditimbang (c). Analisis kadar abu dilakukan sebanyak 3 kali ulangan.

$$
\% \text { Kadar abu }=\frac{(c-a)}{b} \times 100 \%
$$

\section{Analisis kadar protein}

Sampel sebanyak 0.5-1 g ditimbang dengan menggunakan kertas, lalu dimasukan ke tabung destruksi dan ditambahkan katalis kjeltab dan 12.5 $\mathrm{ml}_{2} \mathrm{SO}_{4}$. Kemudian tabung destruksi diletakan pada digestor dan dilakukan proses destruksi pada suhu $415^{\circ} \mathrm{C}$ selama 1 jam. Setelah proses destruksi berlangsung tabung diangkat dan didinginkan selama 1 jam. Kemudian dilakukan proses analisis menggunakan alat kjeltec. Sebelumnya dilakukan analisis terhadap blanko dengan menempatkan tabung destruksi kosong yang akan terisi air suling secara otomatis oleh alat. Setelah itu dilakukan pengesetan tempat tabung destruksi, nomor tabung, bobot sampel, data konversi, dan konsentrasi $\mathrm{HCl}$ terstandarisasi. Data blanko digunakan untuk analisis sampel dan disimpan di dalam alat. Dari hasil analisis pada alat kjeltec akan menunjukan $\% \mathrm{~N}$ dari sampel yang dianalisis. Analisis kadar protein dilakukan sebanyak 2 kali ulangan.

$$
\% \text { Protein }=\% \mathrm{~N} \times 6.25
$$

\section{Analisis kadar lemak}

Sebelum dilakukan analisis kadar lemak, cangkir ekstraksi (extraction cup) dipanaskan selama 1 jam. Kemudian extraction cup ditempatkan dalam desikator selama 1 jam. Lalu ditimbang bobotnya (a). Sebanyak kira-kira 1 gram sampel dibungkus dengan kertas saring (b) dan ditempatkan dalam timbel. Timbel kemudian ditempatkan pada alat soxtec system HT. Sebanyak $40 \mathrm{ml}$ petroleum benzena dimasukan dalam extraction cup. Setelah suhu mencapai $110^{\circ} \mathrm{C}$ extraction cup diletakan pada alat dengan posisi di bawah timbel, sehingga sam- pel terendam. Selama 20 menit sampel dididihkan dengan cara memutar tombol ke arah posisi boiling, lalu dilakukan pembilasan selama 30 menit dengan cara memutar tombol pada posisi rinsing. Pembilasan diulang lagi sambil menutup katup selama 40 menit dan diuapkan selama 10 menit. Extraction cup dilepaskan dari alat dan ditempatkan pada oven selama $1 / 2 \mathrm{jam}$. Lalu extraction cup ditempatkan dalam desikator selama 1 jam. Bobot extraction cup dan lemak yang terbentuk ditimbang (c). Analisis ini dilakukan sebanyak 3 kali ulangan. Kadar lemak dicari dengan persamaan:

$$
\% \text { Kadar lemak }=\frac{(c-a)}{b} \times 100 \%
$$

\section{Analisis kadar karbohidrat}

Analisis kadar karbohidrat dilakukan dengan menggunakan rumus sebagai berikut:

$\%$ Kadar Karbohidrat $=\{100 \%-($ kadar abu + kadar protein + kadar (emak)\}

\section{Uji Toksisitas Akut}

Uji toksisitas dilakukan untuk menentukan $\mathrm{LD}_{50}$ dan $\mathrm{LC}_{50}$. Penentuan $\mathrm{LD}_{50}$ dilakukan berdasarkan metode Lu (1995). Penentuan LC $_{50}$ dilakukan berdasarkan metode Meyer et al. (1982).

\section{Penentuan $L D_{50}$}

Sebanyak 24 ekor tikus galur Spraque dawley dibagi menjadi 4 kelompok dosis, yaitu 0, 5, 10, dan $20 \mathrm{~g} / \mathrm{kg}$ BB dan setiap kelompok terdiri atas 4 ekor. Rebusan sirih merah diberikan secara oral ke tikus sesuai dosisnya, kemudian diukur mortalitas (tingkat kematian) dan bobot selama 1 minggu.

\section{Penentuan $L C_{50}$}

Larva (udang) A.salina dimasukkan dalam air laut yang telah diaerasi. Setelah 48 jam telur akan menetas dan siap digunakan untuk uji $\mathrm{LC}_{50}$. Larva udang dikelompokkan dalam enam sumur dan masing-masing diberi ekstrak air rebusan daun sirih merah dengan konsentrasi $0,200,400,600,800$, dan 1000 ppm. Ke dalam setiap sumur dimasukkan 10 larva udang. Tingkat kematian diamati setelah 24 jam. Setelah itu dilakukan perhitungan $\mathrm{LC}_{50}$. Perhitungan LC ${ }_{50}$ dilakukan dengan cara membuat kurva hubungan antara konsentrasi air rebusan sirih merah (x) terhadap \% kematian (y), sehingga diperoleh persamaan garis $y=0.085 x+13, r=98.63$, dari persamaan tersebut konsentrasi air rebusan sirih merah pada kematian $50 \%$.

\section{Analisis Statistik}

Analisis data menggunakan analisis ragam (ANOVA) rancangan acak lengkap (RAL) pada tingkat kepercayaan $95 \%$ dan taraf $a=0.05$ dan kemudian dilanjutkan dengan uji duncan. Semua data dianalisis dengan menggunakan program SPSS 11.5. 


\section{HASIL DAN PEMBAHASAN}

\section{Proksimat Daun Sirih Merah}

Analisis proksimat terhadap daun sirih merah kering dilakukan untuk mengetahui secara garis besar jumlah zat nutrisi seperti air, abu, protein, karbohidrat, dan lemak yang terkandung pada daun tersebut. Hasil analisis kadar air (Tabel 1) menunjukkan bahwa proses pengeringan dengan oven mampu kadar air sampai dibawah $10 \%$. Dengan demikian, daun sirih merah dapat aman disimpan sebelum digunakan untuk ekstraksi karena kadar air di bawah 10\% dapat mencegah terjadinya proses enzimatik dan kerusakan oleh mikroba seperti bakteri, kapang, dan khamir (Manoi 2006).

Tabel 1. Hasil Analisis Proksimat Daun Sirih Merah (Piper crocatum)

\begin{tabular}{lc}
\hline \multicolumn{1}{c}{ Kadar Proksimat } & Daun Sirih Merah (\%) \\
\hline Air & 9.27 \\
Abu & 14.33 \\
Lemak & 3.96 \\
Protein & 22.63 \\
Karbohidrat & 59.08 \\
\hline
\end{tabular}

Kadar abu merupakan parameter untuk menunjukkan nilai kandungan mineral (bahan anorganik) yang ada di dalam suatu bahan atau produk. Kandungan bahan anorganik yang terdapat di dalam suatu bahan diantaranya kalsium, kalium, fosfor, besi, magnesium, dan lainnya. Kadar abu daun sirih merah (14.33\%) lebih tinggi jika dibandingkan dengan daun kumis kucing $\mathbf{( 7 . 8 9 \% )}$ yang biasa digunakan sebagai bahan baku untuk obat herbal (Kusumaningrum 2005). Hal ini menunjukkan bahwa daun sirih memiliki mineral yang lebih tinggi daripada daun kumis kucing.

Berdasarkan hasil analisis proksimat terlihat bahwa pada daun sirih merah komponen yang terbesar adalah karbohidrat (Tabel 1). Sebagaimana daun-daunan pada umumnya, jenis karbohidrat utama yang terdapat pada daun sirih kemungkinan merupakan serat kasar, seperti lignin dan pektin. Komponen terbesar kedua adalah protein. Kadar protein pada daun sirih merah (22.63\%) lebih tinggi jika dibandingkan dengan daun salam (7.61\%) yang juga digunakan sebagai obat diabetes melitus (Sayekti et al. 1994). Komponen terendah dari daun sirih merah adalah lemak. Kadar lemak pada daun sirih merah (3.96\%) lebih rendah jika dibandingkan dengan daun salam (8.36\%) yang juga digunakan sebagai obat diabetes melitus (Sayekti et al. 1994).

\section{Toksisitas Akut Air Rebusan Daun Sirih Merah}

Bukti empiris menunjukkan bahwa konsumsi air rebusan sirih merah $(P$. crocatum) dapat mengo- bati penderita diabetes mellitus (Duryatmo 2005). Penelitian pra klinis menunjukkan bahwa pemberian air rebusan sirih merah pada tikus diabetes (induksi aloksan sebagai bahan pemicu rusaknya pankreas sehingga tikus diabetes) dengan berbagai dosis selama 10 hari mampu menurunkan kadar gula darah sebesar $10-38 \%$ dan mencegah penurunan berat badan sebesar 5-52\%. Analisis senyawa fitokimia menunjukkan bahwa air rebusan sirih merah mengandung alkaloid, flavonoid, dan tanin (Safithri \& Fahma 2008). Senyawa-senyawa tersebut merupakan senyawa bioaktif antidiabetes dan antioksidan (Rohdiana 2001; Silva et al. 2002; Su et al. 2007; Satyanarayana 2006; Battu et al. 2007; Tapas et al. 2008). Upaya menjaga tidak terjadinya komplikasi penyakit pada penderita diabetes mellitus dapat dilakukan dengan menggunakan obat yang bersifat hipoglikemik, atau dengan mengonsumsi minuman fungsional yang berbahan baku tanaman obat dan rempah yang memiliki aktivitas antioksidasi dan antidiabetes (Rates 2001; Rao et al. 2010).

Berdasarkan hasil uji pra klinis air rebusan daun sirih merah pada tikus diabetes yang diinduksi aloksan tersebut, air rebusan daun sirih merah berpotensi untuk dikembangkan sebagai minuman fungsional atau obat yang dapat dikonsumsi oleh penderita diabetes. Oleh karena itu diperlukan suatu kajian keamanan terhadap air rebusan daun sirih merah, yaitu yang diukur dengan uji toksisitas akut, sehingga dapat diketahui tingkat keaman an pangan fungsional tersebut untuk dikonsumsi oleh penderita diabetes.

Pengujian toksisitas akut air rebusan daun sirih merah menunjukkan bahwa selama 24 jam pertama sampai 7 hari masa percobaan tidak ada hewan yang mati baik untuk kelompok dosis 0, 5, 10, maupun $20 \mathrm{~g} / \mathrm{kg}$ BB. Dengan tidak adanya kematian tikus putih pada semua dosis yang diujikan, maka dapat dikatakan bahwa rebusan sirih merah tidak bersifat toksik. Dengan demikian dianggap semua toksisitas akut dapat diabaikan dan nilai $\mathrm{LD}_{50}$ tidak perlu ditentukan karena sampai tertinggi pada skala Hodge, yaitu dosis $20 \mathrm{~g} / \mathrm{kg}$ BB tidak ada tikus yang mati. Hal ini sesuai dengan klasifikasi toksisitas akut menurut skala Hodge dan Sterner (2005) yang menyatakan bahwa zat kimia dengan nilai LD $_{50} 15 \mathrm{~g} /$ $\mathrm{kg} \mathrm{BB}$ atau lebih bersifat praktis tidak toksik (toksis tinggi, $L_{50}=1-50 \mathrm{mg} / \mathrm{kg}$; toksis sedang, $L_{50}=50$ - $500 \mathrm{mg} / \mathrm{kg}$; toksis ringan, $\mathrm{LD}_{50}=500-5000 \mathrm{mg} /$ $\mathrm{kg})$. Pengamatan berat badan baik sebelum maupun sesudah perlakuan menunjukkan peningkatan berat badan (Tabel 2). Peningkatan berat badan ini tidaklah berbeda nyata untuk semua dosis $(p>0.05)$. Ini berarti perlakuan yang diberikan, yaitu pemberian rebusan sirih merah, tidak mempengaruhi pertumbuhan tikus. Pemberian rebusan daun sirih merah, dengan berbagai dosis $(0,5,10$, maupun $20 \mathrm{~g} / \mathrm{kg}$ $\mathrm{BB})$, yang tidak mempengaruhi pertumbuhan berat 
Tabel 2. Pengaruh Pemberian Air Rebusan Daun Sirih Merah terhadap Berat Badan Tikus

\begin{tabular}{ccccc}
\hline \multirow{2}{*}{ Hari } & \multicolumn{4}{c}{ Rerata berat badan $(\mathrm{g})$} \\
\cline { 2 - 5 } & $\mathbf{0 ~ g / k g ~ b b}$ & \multicolumn{2}{c}{ Kelompok dosis formula minuman terpilih } \\
\cline { 2 - 5 } & $147.0 \pm 17.6^{\mathrm{a}}$ & $148.5 \pm 3.0^{\mathrm{a}}$ & $146.3 \pm 17.7^{\mathrm{a}}$ & $143.0 \pm 14.7^{\mathrm{a}}$ \\
\hline-7 & $161.0 \pm 16.9^{\mathrm{a}}$ & $160.8 \pm 14.6^{\mathrm{a}}$ & $158.8 \pm 19.5^{\mathrm{a}}$ & $157.2 \pm 15.1^{\mathrm{a}}$ \\
0 & $182.8 \pm 15.3^{\mathrm{a}}$ & $182.8 \pm 11.9^{\mathrm{a}}$ & $181.8 \pm 22.6^{\mathrm{a}}$ & $177.5 \pm 15.3^{\mathrm{a}}$
\end{tabular}

Keterangan: Huruf yang sama pada baris yang sama menunjukkan tidak berbeda nyata pada $\mathrm{P}<0.05 ; \mathrm{n}=6$; Perlakuan diberikan selama 7 hari dengan intervalpengamatan 7 hari; -7: masa adaptasi; 0 : awal penimbangan berat badan ; 7 : akhir penimbangan berat badan

Tabel 3. Tingkat Kematian Larva Udang pada Masa Percobaaan selama 24 Jam

\begin{tabular}{ccc}
\hline Konsentrasi $(\mathrm{ppm})$ & \% kematian & LC $_{50}(\mathrm{ppm})$ \\
\hline 0 & 0 & 544.82 \\
200 & 30 & \\
400 & 35 & \\
600 & 50 & \\
800 & 70 & \\
1000 & 85 & \\
\hline
\end{tabular}

badan disebabkan dosis yang diberikan tidak membuat mati tikus atau dikatakan tidak toksik sampai dosis $20 \mathrm{~g} / \mathrm{kg}$ BB sehingga tidak mengganggu metabolisme dalam tubuh tikus.

Penimbangan berat badan dilakukan untuk mengetahui perubahan berat badan sebagai indikator efek samping obat dan bahan kimia (Mounnissamy et al. 2010). Hasil pengukuran berat badan toksisitas akut air rebusan sirih merah (selaras dengan hasil pengujian toksisitas akut ekstrak air panas Trichosanthes cucumerina Linn.yang telah dilaporkan memiliki aktivitas antidiabetes (Arawwawala et al. 2011).

Berdasarkan perhitungan air rebusan sirih merah memiliki nilai $\mathrm{LC}_{50}$ di bawah $1000 \mathrm{ppm}$, yaitu sebesar $544.82 \mathrm{ppm}$ (Tabel 3). Hal ini menunjukkan bahwa rebusan daun sirih merah termasuk ke dalam kategori toksik sedang atau toksik menengah menurut skala toksisitas Hodge dan Sterner. Akan tetapi, nilai tersebut juga menunjukkan bahwa rebusan daun sirih merah memiliki bioaktivitas (aktivitas biologis seperti antibakteri, antikanker, antidiabetes, dan lainnya (Meyer et al. 1982). Salah satu hasil penelitian yang menunjukkan bahwa rebusan daun sirih merah memiliki bioaktivitas adalah penelitian Safithri dan Fahma (2008) yang melaporkan bahwa air rebusan sirih merah dosis $20 \mathrm{~g} / \mathrm{kg}$ BB yang diberikan secara oral pada tikus diabetes, selama 10 hari dapat menurunkan kadar glukosa darahnya sebesar $38 \%$.

\section{KESIMPULAN}

Berdasarkan hasil analisis proksimat daun sirih merah mengandung $9.27 \%$ air, $14.33 \%$ abu, $3.96 \%$ le- mak, $22.63 \%$ protein, dan $59.08 \%$ karbohidrat. Uji toksisitas menunjukkan bahwa dekokta/rebusan daun sirih merah tidak memiliki toksisitas hingga dosis $20 \mathrm{~g} / \mathrm{kg}$ BB. Nilai $\mathrm{LC}_{50}$ untuk air rebusan terjadi pada konsentrasi $544.82 \mathrm{ppm}$. Hal ini menunjukkan bahwa dekokta sirih merah relatif aman dan memiliki potensi bioaktivitas.

\section{DAFTAR PUSTAKA}

Arawwawala M, Thabrew I, \& Arambewela L. 2011. Evaluation of the toxic potential of standardized extracts (hot water extract and cold ethanolic extract) of Trichosanthes cucumerina Linn. aerial parts. BLACPMA, 10, 11-22

Battu GR, Mamidipalli SN, Parimi R, Viriyala RK, Patchula RP \& Mood LR. 2007. Hypoglycemic and anti-hyperglycemic effect of alcoholic extract of Benincasa hispida in normal and in alloxan induced diabetic rats. Phacog Mag, 3, 101-105.

Bowman BA \& Russel RM. 2001. Present Knowledge in Nutrition. ED ke-8. ILSI, Washingthon. DC.

Boyle JP, Honeycutt AA, Narayan KM, Hoergoer TJ, Geiss LS, Chen H, \& Thompson TJ. 2001. Projection of diabetes burden through 2050: Impact of changing demography and disease prevalence in the U.S. Diabetes Care, 24, 1936-1940.

Ceriello A. 2003. New insights on oxidative stress and diabetic complications may lead to a "causal" antioxidant therapy. Diabetes Care, 26, 1589-1596.

Dobretsov M, Romanovsky D, \& Stimers JR. 2007. Early diabetic neuropathy: triggers and mech- 
anism. World J Gastroenterol, 13, 175-191.

Duryatmo S. 2005. Dulu hiasan kini obat. Trubus, 427, 37.

King H, Aubert RE, \& Herman WH. 1998. Global burden of diabetes 1995-2025: Prevalence, numerical estimates and projections. Diabetes Care, 21, 1414-1431.

Kusumaningrum I. 2005. Mempelajari toksisitas minuman seduhan bubuk daun kumis kucing (orthosiphon stamineus benth.) terhadap tikus percobaan secara in vivo [skripsi]. Program Sarjana, IPB, Bogor.

Lu FC. 1995. Toksikologi Dasar: Asas, Organ, Sasaran, dan Penilaian Resiko (Nugroho E, penerjemah). UI Pr, Jakarta.

Manoi F. 2006. Pengaruh cara pengeringan terhadap mutu simplisia sambiloto. Bul Littro, 17(1),1 $-5$.

Maritim AC, Sanders RA, \& Watkins JB. 2003. Diabetes, oxidative stress, and antioxidant: a review. J Biochem Molecular Toxicology, 17, 24-38

Meyer BN et al. 1982. Brine shrimp: A convenient general bioasay for active plant constituents. Planta medica, 45, 31-34.

Mounnissamy VM, Kavimani S, Sankari G, Quine SD, \& Subramani K. 2010. Toxicological Studies on Ayurvedic Formulation Mersina in Albino Rats. Arch Pharm Sci \& Res, 1, 130-137.

Rao MU, Sreenivasulu M, Chengaiah B, Reddy KJ, \& Chetty CM. 2010. Herbal medicines for diabetes mellitus: A review. IJPRIF, 2, 1883-1892.

Rates SM. 2001. Plants as a source of drugs. Toxicon, 39, 603-61.
Rohdiana D. 2001. Aktivitas daya tangkap radikal polifenol dalam daun teh. Maj Farmasi Indonesia, 12, 53-58.

Safithri M \& Fahma F. 2008. Potency of P. crocatum decoction as an antihyperglycemic. Hayati J Biosci, 15, 45-48.

Satyanarayana T, Katyayani BM, Hema Latha E, Anjana AM, \& Chinna EM. 2006. Hypoglycemic and anti-hyperglycemic effect of alcoholic extract of Euphorbia leucophylla in normal and in alloxan induced diabetic rats. Phacog Mag, 2, 244-255.

Sayekti S, Muhtadi A, \& Supriyatna. 1994. Aktivitas hipoglikemik daun salam dan herba bulu lutung. Cermin Dunia Kedokteran, 95, 50-54.

Silva et al. 2002. Structure antioxidant activity relationship of flavonoid: a reexamination. Free Radical Research, 36, 1219-1227.

[SNI] Standar Nasional Indonesia. 1992. SNI 01-28911992, Cara Uji Makanan dan Minuman. Dewan Standardisasi Nasional, Jakarta.

Su X, Duan J, Jiang Y, Duan X, \& Chen F. 2007. Polyphenolic profile and antioxidant activities of Oolong tea infusion under various steeping conditions. Int J Mol Sci, 8, 1196-1205.

Tapas AR, Sakarkar DM, \& Kakde RB. 2008. Flavonoids as nutraceuticals: A review. TJPR, 7, 1089-1099.

Widowati L, Dzulkarnain, \& Sa'roni. 1997. Tanaman Obat Untuk Diabetes Melitus. Cermin Dunia Kedokteran, 116, 53-60.

[WHO] World Health Organization. 1980. Diabetes Mellitus: Report of a study group. Technical Series Report No. 727. WHO, Geneva. 